\title{
PXN Gene
}

National Cancer Institute

\section{Source}

National Cancer Institute. PXN Gene. NCI Thesaurus. Code C104206.

This gene plays a role in cytoskeleton remodeling. 